\title{
Pemanfaatan Limbah Kulit Jagung Untuk Meningkatkan Perekonomian Di Desa Pejok Kecamatan Kepohbaru Kabupaten Bojonegoro
}

\author{
Novi Darmayanti ${ }^{1}$, Desy Ika Febrianti ${ }^{2}$, Siti Ayu Putri Lestari ${ }^{3}$ \\ ${ }^{1,2,3}$ Proram Studi Akuntansi , Fakultas Ekonomi, Universitas Islam Darul Ulum Lamongan \\ Email : novismile_ub@yahoo.com
}

\begin{abstract}
ABSTRAK
Tujuan dari pengabdian kepada masyarakat adalah untuk memberikan percontohan dan pelatihan kepada masyarakat berupa pembuatan kerajinan yang memanfaatkan limbah pertanian kulit jagung sebagai upaya pemanfaatan potensi lingkungan Desa Pejok Kecamamatan Kepohbaru Kabupaten Bojonegoro. Metode yang digunakan adalah pemberian materi dan demonstrasi. Karakteristik masyarakat desa Pejok terkhusus ibu-ibu sebagian besar sebagai ibu rumah tangga, adanya pelatihan ini untuk peningkatan pengetahuan tentang manfaat limbah kulit jagung sebagai bahan baku membuat kerajinan yang memiliki nilai jual. Dalam 6 bulan petani melakukan 2 kali panen. Jika dalam sekali panen petani dapat menghasilkan limbah sebanyak 3 ton, maka dapat di kalkulasikan dalam setengah tahun menghasilkan sebanyak 6 ton. Jika 1 ton menghasilkan 2000 kerajinan yang berdaya jual 50 ribu/kerajinan maka pendapatannya ialah 100.000. Berarti jika 6 ton akan menghasilkan nilai jual 120.000. Jadi usaha pemanfaatan limbah kulit jagung cukup layak untuk dikembangkan dan dapat meningkatkan perekonomian petani atau warga di desa Pejok sekitar $80 \%$ persen.
\end{abstract}

Kata kunci: petani, limbah, perekonomian

\begin{abstract}
The purpose of society service is to provide a model and training for the community in the form of handicraft making which utilizes corn husk agricultural waste as an effort to utilize the environmental potential of Pejok Sub-District, Kepohbaru Village, Bojonegoro Regency. The method used is giving material and demonstration. The characteristics of Pejok village community especially housewives, the existence of this training is to increase knowledge about the benefits of corn husk waste as raw material for making crafts that have a sale value. In 6 months the farmers do 2 harvests. If in one harvest the farmers can produce as much as 3 tons of waste, then it can be calculated in half a year producing as much as 6 tons. If 1 ton produces 2000 handicrafts that sell for 50 thousand / craft then the income is 100,000. Means that if 6 tons will produce a selling value of 120,000. So the business of utilizing corn husk waste is feasible to be developed and can improve the economy of farmers or residents in Pejok village around $80 \%$ percent.
\end{abstract}

Keyword: farmer, waste, economy

\section{PENDAHULUAN}

Kelurahan Pejok merupakan salah satu dari 25 Kelurahan di Kecamatan Kepohbaru, secara geografis kelurahan Pejok merupakan kelurahan yang terjal dari Kabupaten Bojonegoro dengan letak di sebelah Tenggara Kabupaten Bojonegoro. Kelurahan Pejok mempunyai luas wilayah 965,2 Ha dan merupakan wilayah terbesar ke-2 se kabupaten Bojonegoro. Secara administrasi dibagai menjadi 7 RW dan 36 RT. Jumlah penduduk kelurahan Pejok 7543 jiwa dengan jumlah laki-laki 3912 jiwa dan 
jumlah perempuan 3631 jiwa. Mata pencaharian penduduk Kelurahan Pejok mayoritas Petani.

Kelurahan Pejok mempunyai potensi untuk memanfaatkan limbah pertanian yang berupa kulit jagung (klobot) sebagai salah satu sumber mencari kemandirian masyarakat dengan memanfaatkan limbah klobot jagung. Limbah jagung dapat dimanfaatkan sebagai bahan baku kerajinan yang dapat diolah menjadi suatu barang yang memiliki nilai ekonomi yang mampu meningkatkan perekonomian masyarakat kelurahan Pejok. Pemanfaatan ini akan dilakukan berbasis sumber daya lokal dengan memanfaatkan potensi lingkungan sekitar. Pemanfaatan limbah jagung yang diolah atau dimanfaatkan menjadi kerajinan mampu mengurangi sampah pertanian yang terbuang sia-sia.

Tanaman jagung merupakan salah satu makanan pokok di Indonesia yang cukup banyak dikonsumsi sehingga menghasilkan limbah alami dalam jumlah yang cukup berlimpah. Menurut data dari Badan Pusat Statistik (BPS) produksi jagung terus meningkat setiap tahun. Pada tahun 2010, produksi jagung nasional mencapai 18,3 juta ton dan pada tahun 2012 meningkat menjadi 19 juta ton. Kondisi demikian mengindikasikan besarnya peranan jagung dalam pertumbuhan subsektor tanaman pangan dan perekonomian nasional secara umum. Berdasarkan Renstra Kementrian Pertanian (2015-2019) yang ditetapkan melalui Peraturan Menteri Pertanian No19/Permentan/HK.140/4 tahun 2015 terdapat enam sasaran strategis untuk mempercepat pembangunan infrastruktur pertanian di Indonesia, yaitu : swasembada padi, jagung dan kedelai serta peningkatan produksi daging, gula dan peningkatan diversifikasi pangan. Perkembangan produksi jagung nasional pada periode 2011-2015 mengalami peningkatan sebesar $12,41 \%$, sedangkan peningkatan luas panen tidak mengalami peningkatan. Dengan demikian laju peningkatan produksi jagung nasional periode 20112015 didorong oleh peningkatan produktivitas melalui teknologi modern dalam budidaya jagung.

Berdasarkan hasil penelitian (Amzeri, 2018) Persentase petani yang berusaha tani jagung lokal, dimana hasil produksi untuk dikonsumsi sendiri atau keluarga lebih banyak dari pada yang dijual yaitu sekitar $88 \%$ sedangkan sisanya adalah petani yang hasil usahataninya lebih banyak untuk dijual. Untuk usahatani jagung hibrida, sebagain besar petani menggunakan hasil produksinya untuk konsumsi keluarganya. Persentase produksi yang dikonsumsi sendiri berkisar 40-80\%, sedangkan yang dijual berkisar antara $20-60 \%$, dan sebagian kecil dipakai untuk lain-lain seperti diberikan ke tetangga.

Hasil bulir jagung yang dimanfaatkan dalam bidang pangan hanya mewakili 5\% dari keseluruhan tanaman jagung, sedangkan 95\% sisa dari tanaman jagung masuk dalam kategori limbah alami yaitu batang, daun, kulit dan tongkol jagung (Faesal, 2013). Salah satu limbah yang dari tanaman jagung yang belum termanfaatkan secara optimal adalah kulit jagung. Menurut ZERI (Zero Emission Research Initiative), sistem produksi yang sehat adalah sistem produksi yang meniru sistem di alam yang tidak mengenal limbah. Alam selalu berprinsip bahwa sisa sebuah kelompok organisme merupakan makanan bagi kelompok organisme lain. 
Berdasarkan penelitian yang dilakukan oleh Mahardika (2014) limbah organik mencapai angka 70\%, sedangkan limbah non organik mencapai angka 30\%. Salah satu limbah organik yang ada di Indonesia adalah limbah bonggol jagung. Limbah bonggol jagung secara produktivitas per hektar menduduki tempat terendah dibandingkan limbah pertanian lainnya. Menurut penelitian tentang penerapan teknik nontenun pada kulit jagung yang dilakukan oleh Paramita (2010) disebutkan bahwa limbah kulit jagung dapat dimanfaatkan menjadi suatu produk sehingga dapat menambah nilai dari limbah kulit jagung tersebut.

Sedangkan, Niode dan Hambali (2015) menyebutkan bahwa Limbah kulit jagung adalah bahan produktif yang sangat bernilai ekonomis jika dimanfaatkan sebagai bahan baku seni kerajinan. Potensi limbah kulit jagung biasanya hanya dimanfaatkan sebagai pakan ternak, bahan baku pengganti plastik serta bahan baku kerajinan tangan seperti aksesoris rambut, tas, kertas kado dan bunga hias. Namun usaha pemanfaatan kulit jagung belum optimal karena belum seluruh limbah terserap sepenuhnya. Banyaknya kulit jagung dipengaruhi oleh varietas jagungnya, dimana jenis jagung manis memiliki jumlah lembar kelobot lebih banyak dibandingkan dengan jenis jagung pioneer.

Adnan (2006) menyatakan bahwa untuk ukuran daya tarik tertinggi adalah pada kelobot lapisan luar jenis jagung pioneer yaitu $344.49 \mathrm{kgf} / \mathrm{cm} 2$ pada arah pengukuran sejajar serat. Sedangkan nilai laju transmisi uap air jenis manis lapisan luar sebesar $665.49 \mathrm{~g} / \mathrm{m} 2 / 24$ jam sedangkan kelobot jagung pioneer lapisan luar sebesar 570.80 $\mathrm{g} / \mathrm{m} 2 / 24$ jam. Kulit jagung terbukti berkekuatan tinggi pada arah serat memanjang, tahan gesek, tidak berbau, tidak mudah terkontaminasi bakteri, dan memiliki daya serap air yang relatif rendah.

Potensi limbah kulit jagung biasanya hanya dimanfaatkan sebagai pakan ternak, bahan baku pengganti plastik serta bahan baku kerajinan tangan seperti aksesoris rambut, tas, kertas kado dan bunga hias. Menurut Kurniawan (2012) aplikasi yang dapat dikembangkan dalam penerapan hasil penelitian ini diantaranya adalah pembuatan kemasan, wadah dan lampu dengan menggunakan limbah kulit jagung. Pembuatan produk ini ditunjukkan untuk memperlihatkan potensi pemanfaatan limbah kulit yang ada. Namun usaha pemanfaatan kulit jagung belum optimal karena belum seluruh limbah terserap sepenuhnya. Banyaknya kulit jagung dipengaruhi oleh varietas jagungnya, dimana jenis jagung manis memiliki jumlah lembar kelobot lebih banyak dibandingkan dengan jenis jagung pioneer.

Kelobot jagung merupakan bahan kemasan yang mudah didapat, murah dan bersifat biodegradable. Saat ini kelobot jagung masih jarang digunakan untuk mengemas produk dan hanya digunakan untuk produk tertentu seperti dodol dan wajik (jawa) atau wajit (sunda) atau hanya sebatas dimanfaatkan sebagai pakan ternak, sedangkan apabila masyarakat kelurahan Pejok mempunyai kreativitas lebih, maka limbah kulit jagung tidak hanya menjadi limbah tapi mampu menjadi barang yang bernilai jual. Selama ini masyarakat belum terlalu paham memanfaatkan limbah jagung padahal limbah jagung dapat dimanfaatkan sebagai : 1. Bungkus rokok 2. Pakan ternak 3. Bungkus makanan. 
Bahan untuk pembuatan kerajinan dari klobot jagung sangat mudah diperoleh karena tersedia disekitar kita, dan cara pembuatannya pun sangat mudah semua orang bisa membuat baik dalam skala besar maupun untuk untuk keperluan rumah sendiri. Akan tetapi masih kurangnya pengetahuan dan ketrampilan tentang pembuatan kerajinan klobot jagung, membuat masyarakat enggan untuk membuatnya, maka dari itu perlu adanya pelatihan pembuatan kerajinan berbahan dari klobot jagung.

\section{METODE PENELITIAN}

Langkah-langkah untuk mencapai hasil yang diharapkan dari program pemberdayaan pengetahuan masyarakat ini dengan menggunakan metode pelaksanaan antara lain: demonstrasi atau pelatihan dan praktek. Sedangkan metode yang digunakan dalam melakukan pemberdayaan sasaran yaitu: pendekatan sosialisasi program pada tokoh masyarakat seperti ibu-ibu PKK, Fatayat, Jama'ah Yasin, dan santri-santri di pondok pesantren yang ada di desa Pejok dan pendampingan sampai kelompok sasaran bisa melakukannya sendiri. Untuk langkah-langkah operasional yang diperlukan untuk mengatasi permasalahan yang dideskripsikan sebagai berikut: tahap observasi dan identifikasi permasalahan; tahap sosialisasi program kegiatan bagi masyarakat dengan melibatkan seluruh komponen masyarakat; tahap orientasi action lapangan, program pelatihan dan pendampingan. Pembuatan kerajinan kulit jagung berikut ini.

\section{Persiapan bahan.}

Sebagai bahan baku pembuatan kerajianan limbah kulit jagung ialah berupa hasil kulit jagung setelah dipanen yang sudah mongering dan layak untuk dijadikan bahan baku kerajinan. Pemilihan bahan baku ini perlu diperhatikan karena akan berpengaruh dalam proses pembuatnnya.

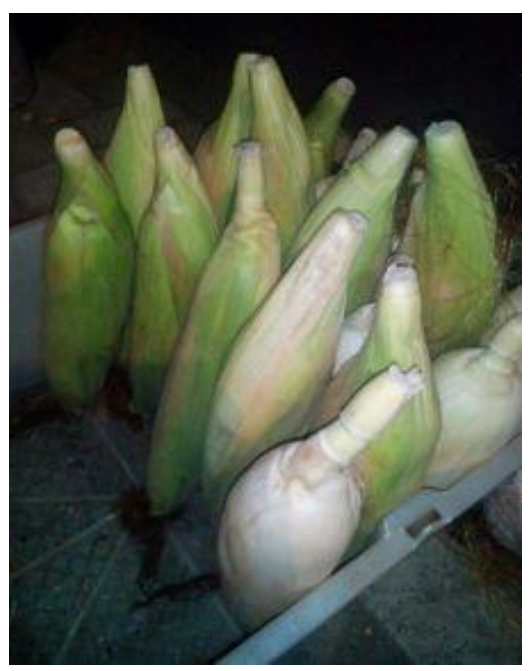

Gambar 1. Jagung 


\section{Pencucian}

Bahan limbah kulit jagung dicuci dalam bak pencucian. Caranya dengan memasukkan kulit jagung ke dalam bak pencucian. Hal yang perlu diperhatikan dalam pencucian ini adalah keselamatan bahan baku, jangan sampai bahan baku pilihan tersebut rusak dan sobek. Proses pencucian ini bertujuan agar kulit jagung yang akan dijadikan kerajinan tampak bersih dan tidak gatal saat disentuh.

\section{Pewarnaan}

Menurut Harry Abrido (2012) perendaman serat alam dengan $\mathrm{NaOH}$ bertujuan untuk meningkatkan ikatan antara serat dan matrik (pekat). Sedangkan senyawa asam asetat bersifat korosif dan berfungsi untuk mengawetkan, melunakkan sekaligus sebagai kualitas atau pengental. Dalam hal ini perendaman pewarnaan ditujukan untuk memperindah kulit jagung yang akan dijadikan kerajinan. Pewarnaan dilakukan dengan cara memasukkan bahan bahan ke dalam bak yang bersih dan berisi air yang sudah dicampur dengan pewarna tekstil (aci). Setelah itu didiamkan selama 30 menit atau lebih agar warnanya meresap ke kulit jagung tersebut. Semakin lama direndam akan semakin bagus hasilnya.

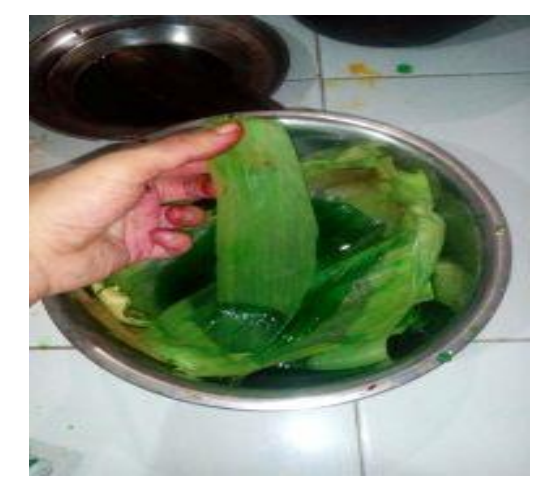

\section{Gambar 2. Pewarnaan Kulit Jagung}

\section{Pengeringan}

Pengeringan dilakukan dengan cara menjemur satu per satu klobot jagung dibawah terik sinar matahari. Pengeringan bertujuan untuk mengeringkan kulit jagung dari proses pewarnaan agar lebih mudah dibentuk untuk dijadikan bahan kerajinan.

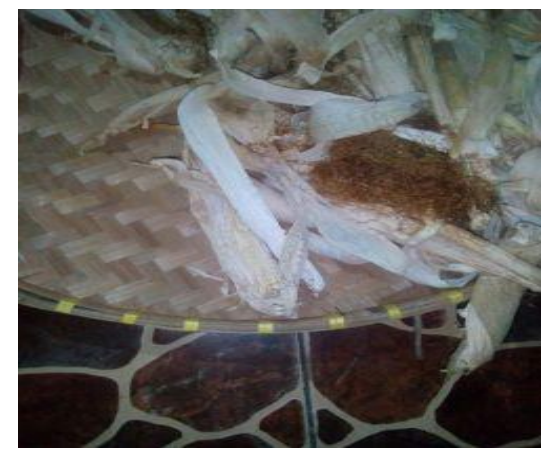

Gambar 3. Pengeringan Kulit Jagung 


\section{Pembuatan Pola}

Pembuatan pola ini dilakukan dengan cara menggunting satu persatu kulit jagung sesuai dengan model yang diharapkan, yang nantinya akan dirangkai menjadi sebuah satu kesatuan yang unik.

\section{Perangkaian}

Perangkaian ini dilakukan dengan cara menyatukan pola satu dengan pola yang lainnya untuk amembentuk sebuah kerajinan yang diinginkan. Alat-alat yang digunakan dalam pelatihan berupa, Klobot Jagung, Kawat/Bendrat, Pewarna Tekstil (aci), Gunting, Lem Tembak, Pot Bunga, Air Panas, Steroform, Ember.

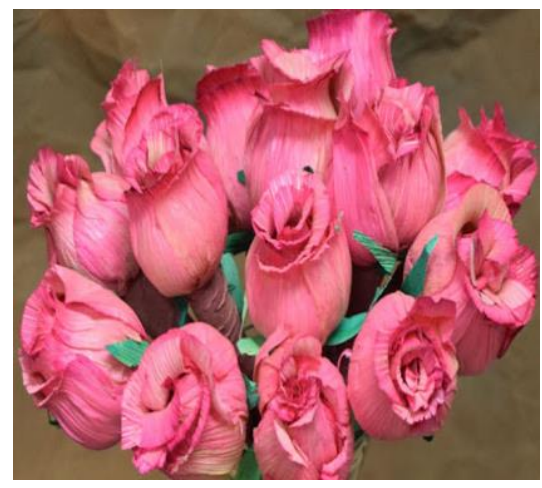

Gambar 4. Perangkaian

\section{HASIL DAN PEMBAHASAN}

Kegiatan pelatihan pembuatan kerajinan klobot jagung adalah sebagai upaya memanfaatkan potensi lingkungan sekitar berupa limbah pertanian .Warga Kelurahan Pejok yang mengikuti kegiatan ini memperoleh pengetahuan tentang pembuatan kerajinan berbahan baku klobot jagung. Pada pembuatan kerajinan ini di gunakan limbah pertanian berupa klobot jagung.

Kulit jagung untuk di buat kerajinan tangan perlu pengolahan terlebih dahulu sebelum di gunakan agar lebih menarik. Kulit jagung yang di gunakan adalah bagian dalam, karena lebih lunak agar mudah di gunakan. Setelah kulit jagung dipisah-pisah dan di pilah, kemudian di lakukan pewarnaan agar mempunyai warna tertentu sesuai dengan kebutuhan. Untuk pewarnaan digunakan pewarnaan tekstil.

Pewarnaan di mulai dengan merebus air yang telah di beri pewarna tekstil kemudian di celupkankulit jagung pada air rebusan pewarna tadi diaduk terus sampai kurang lebih 1 jam sampai warna meresap kedalam kulit jagung. Jika sudah di keringkan dengan sinar matahari. Setelah kering, klobot di bentuk menyerupai bunga dan daun dengan menggunakan gunting dan pensil. Gunting klobot dengan panjang 6-7 cm, lebar 3-4 cm. Bentuk helaian kulit jagung sehingga menjadi kelopak bunga.

Perangkaian pembuatan dahan/ranting agar menyerupai aslinya dengan menggunakan kawat bendrat yang di lilitkan. Gunting kawat dengan panjang 20-25 cm buat lilitan dan bentuk lengkungan dengan bercabang 3-4 cabang, gunakan tang untuk mempermudah pekerjaan ini. Selanjutnya,lipat helaina kulit jagung ukuran 4-6 cm 
melingkari di ujung kawat dan eratkan dengan menggunakan lem tembak, bagian ini akan berfungsi sebagi putik bunga. Sekaligus sebagai basis tempat meletakkan kelopakkelopak bunga yang berjumlah lima.

Tahap selanjutnya, menempelkan kelopak bunga pertama dengan mempereratnya dengan lem tembak. Tambahkan kelopak selanjutnya untuk mengatur posisinya, sekiranya nanti terdapat 4-5 kelopak dan jaraknya semua terbagi rata. Setelah bentuk bunga sudah jadi, tahap akhir adalah finishing akhir.

Berikutnya memilih kulit jagung yang lentur dan tipis untuk di buat daun sebagai pangkal tangkai sampai ujung. Kemudian ambil kulit jagung dan lilitkan di kawat sehingga menutupi semua bagian kawat. Gunakan pot bunga ukuran sedang sebagi wadah untuk tempat bunga kulit jagungnya.

Pelatihan pembuatan kerajinan berbahan baku kulit jagung limbah sisa pertanian memberikan manfaat besar bagi msayarakat kelurahan pejok yaitu adanya peningkatan pengetahuan tentang pemanfaatan limbah sisa pertanian sebagai bahan baku membuat kerajinan yang mempunyai nilai ekonomis. Sehingga masyarakat Desa Pejok, Dusun Sokorejo, Pond Pest Darul Falah, kedepanya bisa membuat sendiri kerajian dari kulit jagung yang memanfaatkan limbah pertanian yang ada di sekitar mereka. Hal ini juga dalam rangka untuk mencapai kemandirian masyarakat untuk memanfaatkan potensi yang ada di sekitar sebagai bahan baku membuat kerajinan untuk mendukung mewujudkan meningkatkan perekonomian antara lain melalui pemanfaatan libah pertanian (klobot jagung) sebagi bahan baku pembuat kerajinan.

\section{SIMPULAN}

Warga Desa Pejok, Dusun Sokorejo, Pondok Pesantren Darul Falah memiliki peningkatan pengetahuan dan keterampilan tentang manfaat bahan sisa limbah pertanian jagung sebagai bahan baku pembuatan kerajinan. Kerajinan bunga yang dihasilkan akan meningkatkan perekonomian masyarakat desa Pejok.

\section{Terimakasih disampaikan kepada:}

1. Warga desa Pejok, dusun Sokorejo, Pondok Pesantren Darul Falah Kepohbaru Bojonegoro, 2019

2. Mahasiswa KKN Unisda Lamongan 2019

3. Rektor Unisda Lamongan beserta civitas Akademika Unisda 2019

4. Serta semua pihak yang ikut serta membantu dalam penyusunan karya ilmiah pengabdian masyarakat ini, kami ucapkan banyak terimakasih.

\section{DAFTAR PUSTAKA}

Abrido, H. S., J. Leonard S., \& Maulida. (2012). Pengaruh Penggunaan Larutan Alkali dalam Kekuatan Bentur dan Uji Degradasi Pada Komposit Termoplastik Berpengisi Serbuk Serabut Kelapa. Jurnal Teknik Kimia USU, Vol. 1, No. 2 (2012). https://jurnal.usu.ac.id/index.php/jtk/article/view/118/312

Adnan, A. A. (2006). Karateristik Fisiko Kimia dan Mekanis Kelobot Jagung Sebagai Bahan Kemasan. Skripsi, Fakutltas Teknologi Pertanian. Bogor:Institut Pertanian. https://repository.ipb.ac.id/jspui/bitstream/123456789/3364/4/F06aaa.pdf 
Amzeri, A. (2018, April). Tinajuan Pekembangan Pertanian Jagung di Madura dan Alternatif Pengolahan Menjadi Biomateri. Jurnal Ilmiah Rekayasa, Volume 11, No, 11( Hlm 78-86).

https://eco-entrepreneur.trunojoyo.ac.id/rekayasa/article/view/4127

Faesal. 2013. Pengolahan Limbah Tanaman Jagung Untuk Pakan Ternak Sapi Potong. Prosiding Seminar Nasional Inovasi Teknologi Pertanian: Jakarta; Badan Litbang Pertanian. http://kalsel.litbang.pertanian.go.id/ind/images/pdf/prosiding/18\%20faesal.pdf

Kurniawan, dicky. 2012. Pemanfaatan limbah kulit jagung dalam aplikasi produk industri. www.fsrd.itb.ac.id.

Mahardika, \& Dewi, F. R. (2014). Analisis Pengembangan Usaha Pemanfaatan Limbah Bonggol Jagung Menjadi Produk Kerajinan Multiguna . Jurnal Manajemen dan Organisasi Vol V, No 3, Desember 2014, 215-226.

https://media.neliti.com/media/publications/111177-ID-analisis-pengembanganusaha-pemanfaatan.pdf

Niode, I. Y., \& Hambali, I. R. (2015). Membangun Wirausaha Melalui Pemanfaatan Limbah Kulit Jagung Bahan Kerajinan Merangkai Bunga Kelompok Usaha Ibu dan Remaja Putri. PENERAPAN IPTEKS.

https://jurnal.unimed.ac.id/2012/index.php/jpkm/article/view/3459

Paramita, N. 2010. Eksplorasi Oleh Serat Jagung (Zea Mays) Melalui Proses Teknik Non Tenun Untuk Alternatif Produk-Produk Kria. Skripsi, Fakultas Seni Rupa dan Desain. Bandung: Institut Teknologi Bandung.

https://multisite.itb.ac.id/kria-senirupa/wp-content/uploads/2011/08/17206022paramita.pdf 